\title{
Aspergillus brasiliensis sp. nov., a biseriate black Aspergillus species with world-wide distribution
}

Correspondence

János Varga

jvarga@cbs.knaw.nl

\section{INTRODUCTION}

Black aspergilli (Aspergillus section Nigri; Gams et al., 1985) have a significant impact on modern society. Many species cause food spoilage, and several are used in the fermentation industry to produce hydrolytic enzymes, such as amylases or lipases, and organic acids, such as citric acid and gluconic acid (Varga et al., 2000). They are also candidates for genetic manipulation in the biotechnology industries as Aspergillus niger used under certain industrial conditions has been granted the GRAS (generally regarded as safe) status by the Food and Drug Administration of the USA government. Although the main source of black aspergilli is

Abbreviations: AFLP, amplified fragment length polymorphism; ITS, intergenic transcribed spacer; SEM, scanning electron microscopy.

The GenBank/EMBL/DDBJ accession numbers for the $\beta$-tubulin, ITS and calmodulin gene sequences determined in this study are shown in Table 1.

The Mycobank accession number for Aspergillus brasiliensis sp. nov. is MB510581 (http://www.mycobank.org).

Neighbour-joining trees based on ITS and calmodulin gene sequence data of Aspergillus section Nigri, a dendrogram based on cluster analysis of AFLP data and tables listing the Aspergillus section Nigri strains used in AFLP analysis and the extrolites produced by the Aspergillus brasiliensis isolates are available with the online version of this paper. soil, members of this section have been isolated from various other sources (Kozakiewicz, 1989; Abarca et al., 2004; Samson et al., 2004). Besides their economical importance, black aspergilli are also important as ochratoxin-producing organisms that contaminate several agricultural products including grape-derived products, coffee and cocoa (Cabañes et al., 2002; Samson et al., 2004).

Black aspergilli are one of the more difficult groups regarding classification and identification. The taxonomy of Aspergillus section Nigri has been studied by many taxonomists and was recently reviewed by Abarca et al. (2004). Nuclear and mitochondrial DNA (mtDNA) polymorphisms and PCRbased techniques led to the recognition of at least two species within the $A$. niger species complex (Aspergillus niger, Aspergillus tubingensis) (Kusters-van Someren et al., 1991; Varga et al., 1994). Regarding other black Aspergillus species, phylogenetic analyses of sequences of the intergenic transcribed spacer and the 5.8S rRNA gene (ITS region) and the D1-D2 region of the 28S rRNA gene indicated that, apart from those mentioned earlier, at least five other species belong to section Nigri: Aspergillus heteromorphus, Aspergillus ellipticus, Aspergillus carbonarius, Aspergillus japonicus and Aspergillus aculeatus (Varga et al., 2000; Parenicova et al., 2001). Several other black Aspergillus species have been 
described recently, including Aspergillus vadensis (de Vries et al., 2005), Aspergillus costaricaensis, Aspergillus piperis, Aspergillus lacticoffeatus and Aspergillus sclerotioniger (Samson et al., 2004) and Aspergillus ibericus (Serra et al., 2006).

During a survey of black Aspergillus isolates collected worldwide, we discovered some strains that did not fit into any species of Aspergillus section Nigri. We have used a polyphasic taxonomic approach in order to determine the delimitation and variability of this novel species. For phenotypic analyses, macro- and micromorphologies of the isolates were examined, and secondary metabolite and enzyme profiles were studied. For genotypic studies, partial sequences of the $\beta$-tubulin and calmodulin genes and the ITS region of the rRNA gene cluster and amplified fragment length polymorphism (AFLP) profiles were analysed (also used by Geiser et al., 1998; Varga et al., 2000; Hong et al., 2006; Perrone et al., 2004, 2006).

\section{METHODS}

The strains examined are listed in Table 1 and were maintained on malt extract autolysate (MEA) agar slants.
Morphological analysis. For macromorphological observations, Czapek yeast autolysate (CYA), MEA agar, Czapek yeast autolysate with $5 \% \mathrm{NaCl}$ (CYAS) agar, yeast extract-sucrose (YES) agar, oatmeal agar (OA) and Czapek agar (CZA) were used (Samson et al., 2004). The isolates were inoculated at three points on each plate of each medium and incubated at $25{ }^{\circ} \mathrm{C}$ in the dark for 7 days. For micromorphological observations, microscopic mounts were made in lactic acid from MEA colonies and a drop of alcohol was added to remove air bubbles and excess conidia. Scanning electron microscopy (SEM) was performed using a Hitachi S570 microscope. For SEM preparation, conidia were transferred to aluminium stubs using double-sided adhesive tape. A small drop of $10 \mathrm{mM}$ ACES buffer containing $0.05 \%$ Tween 80 was added to the conidiophores. The suspension was airdried and coated with platinum. The strains were also inoculated on creatine-sucrose agar (CREA), CYA at $37{ }^{\circ} \mathrm{C}$ and on CYA with $5 \%$ $\mathrm{NaCl}$ (Frisvad \& Samson, 2004).

Extrolite analysis. Extrolites were analysed by HPLC using alkylphenone retention indices and diode array UV-VIS detection as described by Frisvad \& Thrane (1987), with modifications as described by Smedsgaard (1997). Standards of ochratoxin A and B, aflavinines, asperazine, austdiol, kotanin and other extrolites from the collection at Biocentrum-DTU (Denmark) were used to compare the extrolites from the species under study. Pyranonigrin A, tensidol A and $\mathrm{B}$ and pyrophen were identified by comparison with literature UV and MS data (Hiort et al., 2004; Fukuda et al., 2006).

Table 1. Origin and GenBank accession numbers of sequences of the isolates examined in this study

GenBank accession numbers for ITS sequences of other black aspergilli determined in this study: A. costaricensis CBS 115574 ${ }^{\mathrm{T}}$, DQ900602; A. piperis CBS 112811 ${ }^{\mathrm{T}}$, DQ900603; A. lacticoffeatus CBS 101884, DQ900604; A. carbonarius CBS 111.26 ${ }^{\mathrm{T}}$, DQ900605; A. sclerotioniger CBS $115572^{\mathrm{T}}$, DQ900606; A. homomorphus CBS 101889 ${ }^{\mathrm{T}}$, EF166063. GenBank accession number for $\beta$-tubulin gene sequence of A. ibericus ITEM 4776, AM419748.

\begin{tabular}{|c|c|c|c|c|}
\hline \multirow[t]{2}{*}{ Isolate $^{\star}$} & \multirow[t]{2}{*}{ Origin } & \multicolumn{3}{|c|}{ Accession no. } \\
\hline & & ITS & $\beta$-tubulin & Calmodulin \\
\hline CBS $101740^{\mathrm{T}}=\mathrm{IMI} 381727^{\mathrm{T}}=\mathrm{JHC} 614^{\mathrm{T}}$ & Soil, Pedreira, Săo Paulo, Brazil & AJ280010 & $\begin{array}{l}\text { AY820006 } \\
(\text { AM295186) }\end{array}$ & AM295175 \\
\hline JHC 601 & Soil, St Rosa do Viterbo, Brazil & DQ900599 & DQ900609 & - \\
\hline JHC 603 & Soil, St Rosa do Viterbo, Brazil & DQ900601 & DQ900610 & $\dagger$ \\
\hline JHC 605 & Soil, Araçatuba, Săo Paulo, Brazil & - & - & - \\
\hline JHC 606 & Soil, A. Nogueira, Săo Paulo, Brazil & - & - & - \\
\hline JHC 607 & Soil, Campinas, Săo Paulo, Brazil & DQ900600 & DQ900611 & $\dagger$ \\
\hline CBS 246.65=IBT 28083 & Soil, Sydney, New South Wales, Australia & DQ900597 & DQ900607 & - \\
\hline CBS $733.88=$ IBT 28084 & Soil, North Carolina, USA & DQ900598 & DQ900612 & - \\
\hline CBS $116970=$ IBT 28085 & Soil, The Netherlands & DQ900596 & DQ900613 & - \\
\hline ITEM 4540 & $\begin{array}{l}\text { Grapes (Cabernet Sauvignon), Ribatejo } \\
\text { Region, Portugal, } 2001\end{array}$ & AM295180 & AM295183 & AM295178 \\
\hline ITEM 4544 & $\begin{array}{l}\text { Grapes (Tinta Miùda), Ribatejo Region, } \\
\text { Portugal, } 2001\end{array}$ & $\neq$ & AM295184 & AM295177 \\
\hline ITEM 6139 & $\begin{array}{l}\text { Grapes (Vinhão), Vinhos Verdes Region, } \\
\text { Portugal, } 2001\end{array}$ & AM295181 & AM295185 & AM295174 \\
\hline ITEM 4539 & $\begin{array}{l}\text { Grapes (Tinta Barroca), Douro Region, } \\
\text { Portugal, } 2002\end{array}$ & $\neq$ & AM295182 & AM295179 \\
\hline
\end{tabular}

${ }^{*}$ CBS, Centraalbureau voor Schimmelcultures, Utrecht, The Netherlands; JHC, James H. Croft's culture collection, Birmingham, UK; IBT, BioCentrum-DTU, Kgs. Lyngby, Denmark; IMI, CABI Bioscience Genetic Resource Collection, Egham, UK; ITEM, Agri-Food Toxigenic Fungi Culture Collection, Institute of Sciences of Food Production, Bari, Italy.

$\dagger 100 \%$ identity with the deposited sequence AM295175.

$\ddagger 100 \%$ identity with the deposited sequence AM295180. 
Isolation and analysis of nucleic acids. Total nucleic acids were isolated according to the literature (Leach et al., 1986). Fragments containing the region encoding the intergenic transcribed spacer 1 (ITS-1), 5.8S rDNA and intergenic transcribed spacer 2 (ITS-2) were amplified using primers ITS1 and ITS4, as described previously (Varga et al., 2000) and by White et al. (1990). Amplification of part of the $\beta$-tubulin gene was performed using the primers $\mathrm{Bt} 2 \mathrm{a}$ and $\mathrm{Bt} 2 \mathrm{~b}$ (Glass \& Donaldson, 1995; Samson et al., 2004). Amplifications of the partial calmodulin gene were set up as described previously (Serra et al., 2006). Sequence analysis was performed with a Big Dye Terminator Cycle Sequencing Ready Reaction kit for both strands, and the sequences were aligned with the MT Navigator software (Applied Biosystems). All the sequencing reactions were purified by gel filtration through Sephadex G-50 (Amersham Pharmacia Biotech) equilibrated in double-distilled water and analysed on an ABI PRISM 310 Genetic Analyzer (Applied Biosystems). The resulting sequences of all the isolates were aligned by using the CLUSTAL method with the program DNAMAN (Lynnon Corporation). The unique ITS, $\beta$-tubulin and calmodulin sequences were deposited in the GenBank nucleotide sequence database (Table 1).

AFLP analysis. Twenty-three strains belonging to Aspergillus section Nigri were analysed by AFLP analysis (see Supplementary Table S1 available in IJSEM Online). Fungal strains were grown in shake cultures ( 150 r.p.m., $25{ }^{\circ} \mathrm{C}, 2$ days) in Wickerham's medium (40 g glucose, $5 \mathrm{~g}$ peptone, $3 \mathrm{~g}$ yeast extract, $3 \mathrm{~g}$ malt extract and distilled water to 1 1). Genomic DNA was extracted using an E.Z.N.A. Fungal DNA Miniprep kit (Omega Bio-tek), according to the manufacturer's protocol. The DNA was dissolved in sterile water, diluted to $20 \mathrm{ng} \mu \mathrm{l}^{-1}$ and stored at $-20{ }^{\circ} \mathrm{C}$.

We used an AFLP Microbial Fingerprinting kit (Applied BiosystemsPerkin-Elmer Corporation) according to the manufacturer's instructions using primer combinations according to Perrone et al. (2006). Peak height thresholds were set at 200. Genotyper software (Applied Biosystems) was set to medium smoothing. Bands of the same size in different individuals were assumed to be identical and to represent the same allele. Bands of different sizes were treated as independent loci with two alleles (present and absent). Data were analysed with an AFLP manager database developed by ACGT BioInformatica S.r.l. and were exported in a binary format with ' 1 ' for the presence of a band/peak and ' 0 ' for its absence. For clustering two different analyses were performed, fragments between 100 and 500 bp and between 200 and $500 \mathrm{bp}$ were analysed with NTSYs software by using the Dice similarity coefficient and clustered by using the unweighted pair group method (UPGMA) (Nei \& Li, 1979).

Analysis of sequence data. Sequence alignments were performed by using CLUSTAL_X (Thompson et al., 1997) and improved manually. Evolutionary distances between the sequences were calculated using Kimura's formula (Kimura, 1980) with the program DNADIST of the PHYLIP program package (Felsenstein, 1995). Phylogenetic trees were prepared by using the neighbour-joining method (Saitou \& Nei, 1987) with the program NEIGHBOR of the PHYLIP package. Bootstrap values were calculated from 1000 replications of the bootstrap procedure using programs SEQBOOT, DNADIST, NEIGHBOR and CONSENSE of the package (Felsenstein, 1985, 1995). For parsimony analysis, the PAUP* version 4.0 software was used (Swofford, 2000). Aspergillus flavus CBS $100927^{\mathrm{T}}$ was used as an outgroup in these experiments.

\section{RESULTS AND DISCUSSION}

Isolates of the novel species described below have an unique echinulate conidium surface ornamentation, in contrast to all other members of the Aspergillus niger complex or the A. niger clade in Samson et al. (2004). The conidia of the novel species were more similar to those of A. aculeatus and $A$. carbonarius, but differed from those of the former species in being biseriate and from those of $A$. carbonarius in being much smaller. Physiological features such as very good growth and sporulation at $37^{\circ} \mathrm{C}$, poor growth but strong acid production on CREA agar, and very good growth and sporulation on CYA agar with $5 \% \mathrm{NaCl}$ were indicative of a close relationship with $A$. niger and $A$. tubingensis. The strong acid production on CREA agar indicates that the novel species can produce citric acid. Like $A$. niger, the novel species also produces xylanases and thermostable $\beta$-xylosidases (Pedersen et al., 2007). Regarding extrolite profiles, the isolates of the novel species produced naphtho- $\gamma$-pyrones (including aurasperone B), pyrophen (Barnes et al., 1990) and tensidol A and B (Fukuda et al., 2006), in common with A. niger and $A$. tubingensis, but also produced several unique compounds (see Supplementary Table S2 in IJSEM Online), justifying the treatment of the isolates as representing a separate species. None of the isolates were found to produce ochratoxin A, kotanins, funalenone, antafumicins, asperazine or pyranonigrins, common to other species in the $A$. niger complex (Table 2). Two isolates produced large white sclerotia (ITEM 4544 and ITEM 6139). These strains contained the same sclerotial indol alkaloids as A. piperis and A. costaricaensis (Samson et al., 2004). From a chemotaxonomic point of view, we regard isolates to be members of a novel species if they produce unique combinations of extrolites not seen in any other species. In this case some species-specific, but not yet structure-elucidated, extrolites were present in the novel species, whereas certain extrolites regarded as being species specific for other species in Aspergillus section Nigri were not present in the novel species.

In previous studies, a wide-ranging variation in mtDNA restriction fragment length polymorphism profiles was observed both among collection strains and in natural populations of the A. niger species complex (Varga et al., 1993, 1994). Most isolates were classified as A. niger or A. tubingensis according to their HaeIII-BglII digested mtDNA patterns. A. niger and A. tubingensis were grouped into five and six mtDNA types, respectively. However, six of the 73 Brazilian isolates examined exhibited unique mtDNA profiles using HaeIII and BglII restriction enzymes (Varga et al., 1994, 2000). These isolates also differ from other isolates belonging to Aspergillus section Nigri in their SmaIdigested nuclear DNA hybridization patterns using rRNA probes (Varga et al., 1994, 2000). Later, a survey of isolates held in the culture collection of the Centraalbureau voor Schimmelcultures (CBS) assigned to either the A. niger or A. tubingensis species, and another survey of black aspergilli isolated from grapes in Portugal using sequence analysis of the ITS, $\beta$-tubulin and calmodulin genes, identified another three and four isolates, respectively, which were found to be related to the Brazilian strains. These strains were isolated from soil from Brazil, Australia, USA and 
Table 2. Morphological characteristics and extrolite production of species belonging to the $A$. niger species complex in Aspergillus section Nigri

\begin{tabular}{|c|c|c|c|c|}
\hline Species & $\begin{array}{l}\text { Conidial size } \\
(\mu \mathrm{m})\end{array}$ & $\begin{array}{l}\text { Vesicle size } \\
(\mu \mathrm{m})\end{array}$ & $\begin{array}{l}\text { Colour and size of } \\
\text { sclerotia }(\mathrm{mm})\end{array}$ & Extrolites produced \\
\hline A. brasiliensis sp. nov. & $3.5-4.5$ & $30-45$ & $\begin{array}{l}\text { Found only in some } \\
\text { strains, white, } 1-1.5\end{array}$ & $\begin{array}{l}\text { Naphtho- } \gamma \text {-pyrones (including aurasperone B), } \\
\text { pyrophen, tensidol A and B, (dihydrocarolic acid, } \\
\text { 14-epi-14-hydroxy-10,23-dihydro-24,25-dehydro- } \\
\text { aflavinine, 10,23-dihydro-24,25-dehydro-aflavinine) }{ }^{*}\end{array}$ \\
\hline A. costaricaensis & $3.1-4.5$ & $40-80$ & Pink to yellow, $1.2-1.8$ & $\begin{array}{l}\text { Aflavinines (see above), corymbiferan lactones, } \\
\text { funalenone, naphtho- } \gamma \text {-pyrones }\end{array}$ \\
\hline A. foetidus & $3.5-4.5$ & $50-80$ & - & $\begin{array}{l}\text { Antafumicins, asperazine, funalenone, naphtho- } \gamma \text { - } \\
\text { pyrones, pyranonigrin A }\end{array}$ \\
\hline A. lacticoffeatus & $3.4-4.1$ & $40-65$ & - & Kotanins, ochratoxin A, pyranonigrin A, tensidol B \\
\hline A. niger & $3.5-5$ & $45-80$ & - & $\begin{array}{l}\text { Funalenone, (kotanins), naphtho- } \gamma \text {-pyrones, (ochra- } \\
\text { toxin A), pyranonigrin A, pyrophen, tensidol A and B }\end{array}$ \\
\hline A. piperis & $2.8-3.6$ & $40-55$ & $\begin{array}{l}\text { Yellow to pink-brown, } \\
1.0-1.7\end{array}$ & $\begin{array}{l}\text { Aflavinines (see above), naphtho- } \gamma \text {-pyrones, pyrano- } \\
\text { nigrin A }\end{array}$ \\
\hline A. tubingensis & $3-5$ & $40-80$ & White to pink, $0.5-0.8$ & $\begin{array}{l}\text { Asperazine, funalenone, naphtho- } \gamma \text {-pyrones, pyrano- } \\
\text { nigrin } \mathrm{A} \text {, tensidol A and B }\end{array}$ \\
\hline A. vadensis & $3-4$ & $25-35$ & - & $\begin{array}{l}\text { Asperazine, funalenone, naphtho- } \gamma \text {-pyrones, nigragil- } \\
\text { lin, polar kotanin-like compound }\end{array}$ \\
\hline
\end{tabular}

${ }^{\star}$ These extrolites were only produced by isolates producing sclerotia.

The Netherlands, and from grape berries from Portugal (Table 1).

We examined the genetic relatedness of these isolates to other black aspergilli using sequence analysis of the ITS region of the rRNA gene cluster and parts of the calmodulin and $\beta$-tubulin genes. The isolates were found to form a monophyletic clade supported by high bootstrap values on phylogenetic trees based on $\beta$-tubulin, ITS and calmodulin sequence data (Fig. 1 and Supplementary Figs S1 and S2 in IJSEM Online). During analysis of part of the $\beta$-tubulin gene, 392 characters were analysed. Among the 193 polymorphic sites, 160 were found to be phylogenetically informative. The neighbour-joining tree based on partial $\beta$-tubulin gene sequences is shown in Fig. 1. The topology of the tree is the same as that of a parsimony tree constructed by using the program PAUP (length, 414 steps; consistency index, 0.6836; retention index, 0.8039). The calmodulin dataset included 671 characters, with 283 parsimony informative characters. The topologies of the neighbourjoining tree (Supplementary Fig. S1) and the parsimony tree were the same (tree length, 718; consistency index, 0.6964; retention index, 0.8546). The ITS dataset included 479 characters with 70 parsimony informative characters. The neighbour-joining tree shown in Supplementary Fig. S2 has the same topology as the parsimony tree (tree length, 139; consistency index, 0.8849; retention index, 0.9342).

These isolates also formed a well-defined cluster on an UPGMA tree based on AFLP data (see Supplementary Fig. S3 in IJSEM Online). AFLP data have the special advantage of containing both individual (fingerprinting) and species-specific information. Our data indicate that these isolates are well separated from other black aspergilli based on all molecular approaches used. During AFLP analysis, clear polymorphisms both within and between species were obtained for each of the four primer pairs. Each primer combination consistently distinguished the nine different species of black aspergilli analysed by AFLP with similarity among the different species of less than $20 \%$ (Supplementary Fig. S3). The 11 strains that were grouped by sequence analysis as A. brasiliensis formed a main AFLP cluster that was clearly differentiated from all the other species of section Nigri, but they showed a great degree of genetic variability among each other with a similarity of $25 \%$ (Dice similarity index). In particular, two main clusters were formed within the A. brasiliensis group; the first grouped the four Portuguese strains from grapes at a similarity of $52 \%$, and the second one grouped at a similarity of $42 \%$ all other strains isolated from soil from Brazil, Australia, USA and The Netherlands.

Our Aspergillus species concept is based on a polyphasic approach (Frisvad \& Samson, 2004): A novel species is different from any other species in a diagnostic sense in both phenotypic and genotypic features. Here we have used morphological, physiological and chemotaxonomical features to characterize the phenotype and sequencing of three genes combined with AFLP results to characterize the isolates genotypically. Because the isolates were unique with regard to morphology, extrolite profiles and genotypic features, we propose the name Aspergillus brasiliensis sp. nov. for these isolates.

The name brasiliensis refers to the locality where the culture was isolated. Since its discovery the species has also been 


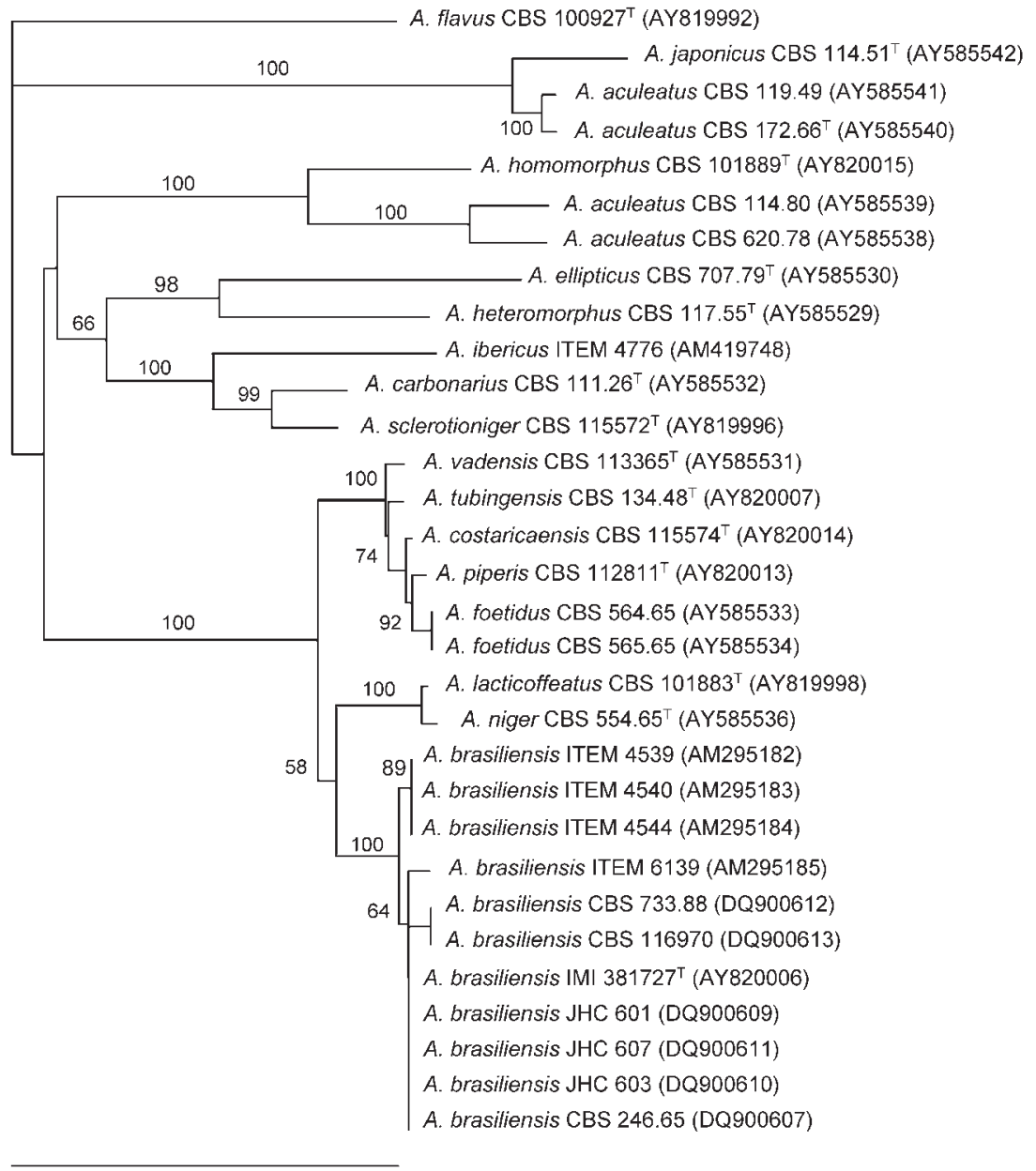

Fig. 1. Neighbour-joining tree based on $\beta$ tubulin sequence data of Aspergillus section Nigri. Numbers above branches are bootstrap values. Only values above $50 \%$ are indicated. Bar, genetic distance. found in other localities, but we propose to maintain the name to avoid confusion because the epithet has been used and cited in various publications.

\section{Latin diagnosis of Aspergillus brasiliensis Varga, Frisvad et Samson sp. nov.}

Coloniae post 7 dies $71-76 \mathrm{~mm}$ diam in agaro CYA et CYAS dicto, in MEA $52-70 \mathrm{~mm}$, in YES $75-80 \mathrm{~mm}$, in agaro farina avenacea confecto $32-36 \mathrm{~mm}$, in CREA $32-44 \mathrm{~mm}$. Coloniae primum albae, deinde obscure brunneae vel atrae, reverseum cremeum vel dilute brunneum. Conidiorum capitula primum globosa, deinde radiantia, nonnumquam in nonnullas columnas divisa; stipes $700-1700 \times 8-13 \mu \mathrm{m}$, crassitunicatus, levis, dilute brunneus; vesiculae 30-45 $\mu \mathrm{m}$ diam, fere globosae; capitula biseriata; metulae quasi totam superficiem vesiculae obtegentes, 22-30 × 3-6 $\mu \mathrm{m}$; phialides lageniformes, 7-9 × 3-4 $\mu \mathrm{m}$; conidia subglobosa, 3.5-4.8 $\mu \mathrm{m}$ diam, echinulata. Sclerotia haud visa.

Typus siccus in herb. CBS $101740^{\mathrm{T}}\left(=\mathrm{IMI} 381727^{\mathrm{T}}=\mathrm{IBT}\right.$ $21946^{\mathrm{T}}$ ) et ex-typus vivus, isolatus e solo in Pedreira, Săo Paulo, Brasilia.

\section{Description of Aspergillus brasiliensis Varga, Frisvad \& Samson sp. nov.}

Aspergillus brasiliensis (bra.si'li.en'sis. N.L. masc. adj. brasiliensis from Brazil, the place of isolation).

Colony diameters at 7 days: CYA at 25 and $37{ }^{\circ} \mathrm{C}$, and CYAS at $25{ }^{\circ} \mathrm{C}$ : 71-76 mm; MEA $52-70 \mathrm{~mm}$; YES 75$80 \mathrm{~mm}$; OA 32-36 mm; CREA 32-44 mm, poor growth, strong acid production. Colony first white then dark brown to black (Fig. 2). Exudates absent, reverse cream-coloured to light brown. Conidial heads globose at first and later radiate occasionally developing into several conidial columns; stipes 700-1700 ×8-13 $\mu \mathrm{m}$, walls thick, smooth, pale brown; vesicles 30-45 $\mu \mathrm{m}$ wide, nearly globose; biseriate; metulae covering virtually the entire surface of the vesicle, measuring 22-30 $\times 3-6 \mu \mathrm{m}$; phialides flask-shaped, 7-9 $\times 3-4 \mu \mathrm{m}$; conidia subglobose, 3.5-4.8 $\mu \mathrm{m}$ in diameter, echinulate. No sclerotia observed in the culture ex type. All isolates produced several naphtho- $\gamma$-pyrones (including aurasperone $\mathrm{B}$ ), tensidol $\mathrm{A}$ and $\mathrm{B}$ and pyrophen.

The type strain, CBS $101740^{\mathrm{T}} \quad\left(=\mathrm{IMI} 381727^{\mathrm{T}}=\mathrm{IBT}\right.$ $21946^{\mathrm{T}}$ ), was isolated from soil, Pedreira, Săo Paulo, 

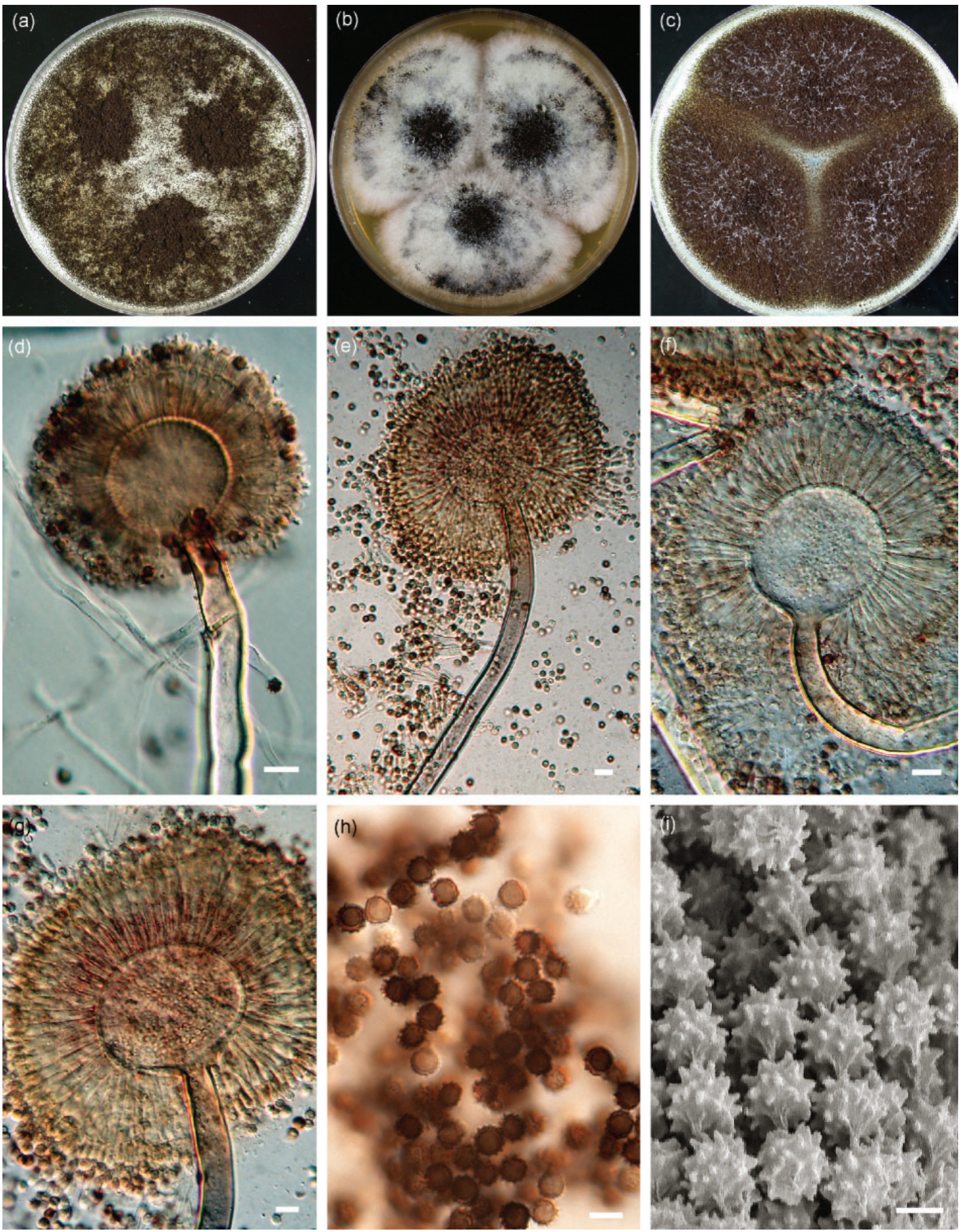

Fig. 2. Aspergillus brasiliensis sp. nov. CBS 101740 ${ }^{\top}$. (a) Colonies on CYA; (b) colonies on OA; (c) colonies on MEA; (d-g) conidiophores; (h) conidia under light microscope; (i) conidia as seen using SEM. Bars, $10 \mu \mathrm{m}$ (d-h) and $5 \mu \mathrm{m}$ (i). 
Brasil. Isolates ITEM 4544 and ITEM 6139 produce large white sclerotia.

\section{ACKNOWLEDGEMENTS}

We thank Gaetano Stea from the Institute of Sciences of Food Production, CNR, Bari, Italy for his valuable technical assistance and Armando Venancio from Centro de Engenharia Biologica, Universidade do Minho, Braga, Portugal for providing the Portugal strains. This research was supported in part by a grant from the Italian Ministry of Education, University and Research (MIUR) Project 12818 - SIVINA 'Individuazione di metodologie innovative prontamente trasferibili per migliorare la sicurezza dei vini rossi di qualità del Salento'.

\section{REFERENCES}

Abarca, M. L., Accensi, F., Cano, J. \& Cabañes, F. J. (2004). Taxonomy and significance of black aspergilli. Antonie Van Leeuwenhoek 86, 33-49.

Barnes, C. L., Steiner, J. R., Torres, E., Pacheco, R. \& Marquez, H. (1990). Structure and absolute configuration of pyrophen, a novel pyrone derivative of L-phenylalanine from Aspergillus niger. Int J Pept Protein Res 36, 292-296.

Cabañes, F. J., Accensi, F., Bragulat, M. R., Abarca, M. L., Castella, G., Minguez, S. \& Pons, A. (2002). What is the source of ochratoxin A in wine? Int J Food Microbiol 79, 213-215.

de Vries, R. P., Frisvad, J. C., van de Vondervoort, P. J. I., Burgers, K., Kuijpers, A. F. A., Samson, R. A. \& Visser, J. (2005). Aspergillus vadensis, a new species of the group of black Aspergilli. Antonie Van Leeuwenhoek 87, 195-203.

Felsenstein, J. (1985). Confidence limits on phylogenies: an approach using the bootstrap. Evolution 39, 783-791.

Felsenstein, J. (1995). PHYLIP (phylogeny inference package), version 3.57c. Distributed by the author. Department of Genome Sciences, University of Washington, Seattle.

Frisvad, J. C. \& Samson, R. A. (2004). Polyphasic taxonomy of Penicillium subgenus Penicillium. A guide to identification of food and air-borne terverticillate Penicillia and their mycotoxins. Stud Mycol 49, 1-173.

Frisvad, J. C. \& Thrane, U. (1987). Standardized high performance liquid chromatography of 182 mycotoxins and other fungal metabolites based on alkylphenone retention indices and UV-VIS spectra (diode-array detection). J Chromatogr 404, 195-214.

Fukuda, T., Hasegawa, Y., Hagimori, K., Yamaguchi, Y., Masuma, R., Tomoda, H. \& Ōmura, S. (2006). Tensidols, new potentiators of antifungal miconazole activity, produced by Aspergillus niger FKI2342. J Antibiot 59, 480-485.

Gams, W., Christensen, M., Onions, A. H. S., Pitt, J. I. \& Samson, R. A. (1985). Infrageneric taxa of Aspergillus. In Advances in Penicillium and Aspergillus Systematics, pp. 55-61. Edited by R. A. Samson \& J. I. Pitt. New York: Plenum Press.

Geiser, D. M., Frisvad, J. C. \& Taylor, J. W. (1998). Evolutionary relationships in Aspergillus section Fumigati inferred from partial $\beta$-tubulin and hydrophobin DNA sequences. Mycologia 90, 831-845.

Glass, N. L. \& Donaldson, G. C. (1995). Development of primer sets designed for use with the PCR to amplify conserved genes from filamentous ascomycetes. Appl Environ Microbiol 61, 1323-1330.

Hiort, J., Maksimenka, K., Reichert, M., Perovic-Ottstadt, S., Lin, W. H., Wray, V., Steube, K., Schauman, K., Weber, H. \& other authors
(2004). New natural products from the sponge-derived fungus Aspergillus niger. J Nat Prod 67, 1532-1543.

Hong, S. B., Cho, H. S., Shin, H. D., Frisvad, J. C. \& Samson, R. A. (2006). Novel Neosartorya species isolated from soil in Korea. Int J Syst Evol Microbiol 56, 477-486.

Kimura, M. (1980). A simple method for estimating evolutionary rates of base substitutions through comparative studies on nucleotide sequences. J Mol Evol 16, 111-120.

Kusters-van Someren, M. A., Samson, R. A. \& Visser, J. (1991). The use of RFLP analysis in classification of the black Aspergilli: reinterpretation of Aspergillus niger aggregate. Curr Genet 19, 21-26.

Kozakiewicz, Z. (1989). Aspergillus species on stored products. Mycol Pap 161, 1-188.

Leach, J., Finkelstein, D. B. \& Rambosek, J. A. (1986). Rapid miniprep of DNA from filamentous fungi. Fungal Genet Newsl 33, $32-33$.

Nei, M. \& Li, W. H. (1979). Mathematical model for studying genetic variation in terms of restriction endonucleases. Proc Natl Acad Sci U S A 76, 5269-5273.

Parenicova, L., Skouboe, P., Frisvad, J., Samson, R. A., Rossen, L., Hoor-Suykerbuyk, M. \& Visser, J. (2001). Combined molecular and biochemical approach identifies Aspergillus japonicus and Aspergillus aculeatus as two species. Appl Environ Microbiol 67, 521-527.

Pedersen, M., Lauritzen, H. K., Frisvad, J. C. \& Meyer, A. S. (2007). Identification of thermostable $\beta$-xylosidase activities produced by Aspergillus brasiliensis and Aspergillus niger. Biotechnol Lett. doi:10.1007/s10529-007-9314-9

Perrone, G., Susca, A., Stea, G. \& Mulè, G. (2004). PCR assay for identification of Aspergillus carbonarius and Aspergillus japonicus. Eur J Plant Pathol 110, 641-649.

Perrone, G., Mulè, G., Susca, A., Battilani, P., Pietri, A. \& Logrieco, A. (2006). Ochratoxin A production and AFLP analysis of Aspergillus carbonarius, Aspergillus tubingensis, and Aspergillus niger strains isolated from grapes in Italy. Appl Environ Microbiol 72, 680-685.

Saitou, N. \& Nei, M. (1987). The neighbor-joining method: a new method for reconstructing phylogenetic trees. Mol Biol Evol 4, 406-425.

Samson, R. A., Houbraken, J. A. M. P., Kuijpers, A. F. A., Frank, J. M. \& Frisvad, J. C. (2004). New ochratoxin or sclerotium producing species in Aspergillus section Nigri. Stud Mycol 50, 45-61.

Serra, R., Cabañes, F. J., Perrone, G., Castella, G., Venancio, A., Mule, G. \& Kozakiewicz, Z. (2006). Aspergillus ibericus: a new species of section Nigri isolated from grapes. Mycologia 98, 295-306.

Smedsgaard, J. (1997). Micro-scale extraction procedure for standardized screening of fungal metabolite production in cultures. J Chromatogr A 760, 264-270.

Swofford, T. (2000). PAUP*: Phylogenetic analysis using parsimony, version 4.0. Sunderland, MA: Sinauer Associates.

Thompson, J. D., Gibson, T. J., Plewniak, F., Jeanmougin, F. \& Higgins, D. G. (1997). The CLUSTAL_X windows interface: flexible strategies for multiple sequence alignment aided by quality analysis tools. Nucleic Acids Res 25, 4876-4882.

Varga, J., Kevei, F., Fekete, C., Coenen, A., Kozakiewicz, Z. \& Croft, J. H. (1993). Restriction fragment length polymorphisms in the mitochondrial DNAs of the Aspergillus niger aggregate. Mycol Res 97, 1207-1212.

Varga, J., Kevei, F., Debets, F., Kozakiewicz, Z. \& Croft, J. H. (1994). Mitochondrial DNA restriction fragment length polymorphisms in field isolates of the Aspergillus niger aggregate. Can J Microbiol 40, 612-621. 
Varga, J., Kevei, F., Hamari, Z., Tóth, B., Téren, J., Croft, J. H. \& Kozakiewicz, Z. (2000). Genotypic and phenotypic variability among black Aspergilli. In Integration of Modern Taxonomic Methods for Penicillium and Aspergillus Classification, pp. 397-411. Edited by R. A. Samson \& J. I. Pitt. Amsterdam: Harwood Academic Publishers.
White, T. J., Bruns, T., Lee, S. \& Taylor, J. (1990). Amplification and direct sequencing of fungal ribosomal RNA genes for phylogenetics. In PCR Protocols: A Guide to Methods and Applications, pp. 315-322. Edited by M. A. Innis, D. H. Gelfand, J. J. Sninsky \& T. J. White. San Diego: Academic Press. 